\title{
CHALLENGES TO STRUCTURAL GLASS: WHAT HAVE BEEN ALREADY DONE?
}

\author{
Tomas Serafinavičius ${ }^{1}$, Audronis Kazimieras Kvedaras ${ }^{2}$
}

Vilnius Gediminas Technical University, Sauletekio al. 11, LT-10223 Vilnius, Lithuania

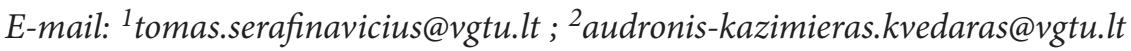

Received 201101 21; accepted 20100421

\begin{abstract}
The paper gives a literature review and systematic scheme of scientific articles in the field of structural glass by applying testing methods and theoretical evaluations. It seems to be an important issue because currently the World feels like a surge of activity and challenges a new influx of glass and light. The summary of the review given at the end of the paper also reveals less investigated areas in the field of structural glass application. The main objectives and tasks for possible and the most important directions for further investigations are formulated on the basis of this review.
\end{abstract}

Keywords: structural glass, laminated glass, tempered glass, behaviour of structure, structural elements, systematic scheme.

\section{Introduction to Structural Glass and Case Studies}

Transparency is the main challenge to the construction of glass. Today, the use of structural glass has become increasingly important as the major part of it is used not only for in door or window manufacturing, but also applied considering broader aspects. Certainly, glass can be excellent material for building responsible structures. The properly designed glass structure can withstand considerable loads and act as the main load bearing element of buildings, often as columns and roof beams, stairs, canopy racks, etc.

During the last 25 years, some glass buildings have been already implemented on a worldwide scale. Apple stores as the most famous examples of structures built of glass are opened in Munich (Fig. 1), Shanghai, New York and elsewhere around the world. The main aim of the Apple store in New York was to design all load bearing structures from glass in order to make the building more transparent both from outside and inside. First of all, an internal stairway and bridge from structural glass were designed, constructed and built. These elements demanded the most attention and efforts regarding the characteristics of connecting ele- ments. The walls of the building were made of bonding 3 glass sheets while its roof beams were produced using 5 sheets of glass. Special metal fitting details at beam supports between the glass plates of beam webs were glued together. The implementation of this pro-

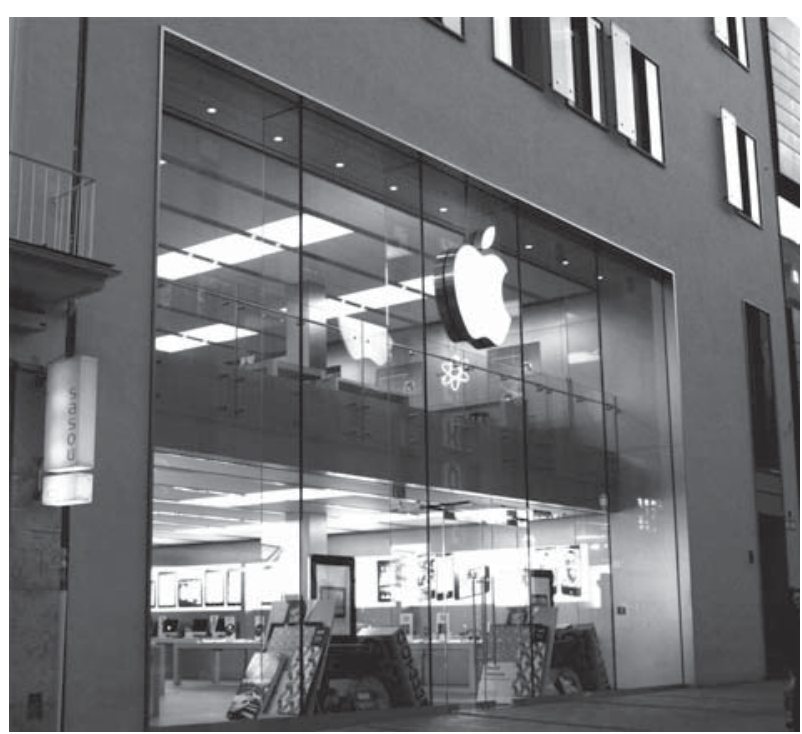

Fig. 1. Full glass façade Apple store in Munich, Germany (photo by T. Serafinavičius) 
ject from designing to construction covered a period of 5 years (2001-2006). The authors mentioned about further researches in order to find more improved glass bearing elements of connecting nodes, giving special focus on cleaning the surfaces of structures during their maintenance (O'Callaghan et al. 2007).

Also, fully transparent glass pavilions in full scale in Aachen, Germany (Wellershoff et al. 2003) and Delft, The Netherlands with a scale of 1:8 using glass beams with steel reinforcement (Bos et al. 2005) were designed. One of the most important goals of these glass pavilions is to carry out scientific research in order to investigate the behaviour of loaded glass elements and structure as a whole as far as possible under natural conditions. Most of conducted research has been performed applying individual and separate elements. Therefore, the focus of researchers was more concentrated on the behaviour of the whole structure and the columns connecting nodes as well as on the beams with steel reinforcement. In addition, a glass dome and pavilions for commercial use have also been built. One of these buildings is erected in the Netherlands (Fig. 2).

A courtyard between two listed buildings was to be covered with a transparent all-glass roof and used as a foyer (Fig. 3). The roof was not to cost more than a good-quality steel structure with glass covering. Gently sloping construction was spanned across the almost square space at a height of about $15 \mathrm{~m}$. Load-bearing structure comprises a grid of beams. Five compound primary beams are roughly $14 \mathrm{~m}$ long and consist of offset parallel glass fins, the zigzag the splayed form of which is based on the approximation of the moment curve and on available glass sizes. In comparison to an arched form, these elements could be manufactured without laser cutting, and with less waste through off cuts (Detail.de).

The narrow focus on one object only discussed in this article illustrates the need for more detailed research on glass structures in order to determine the areas that are intensively investigated and those that are weak as well as the problems that might come to use glass in modern or renovated construction.

This paper gives a brief overview of glass structural elements (beams, columns and plates) and the problems of their connection and design techniques, including characteristics of design codes. Conclusions include the most and least investigated areas associated with glass structures and a number of proposals to focus while choosing areas for further study.

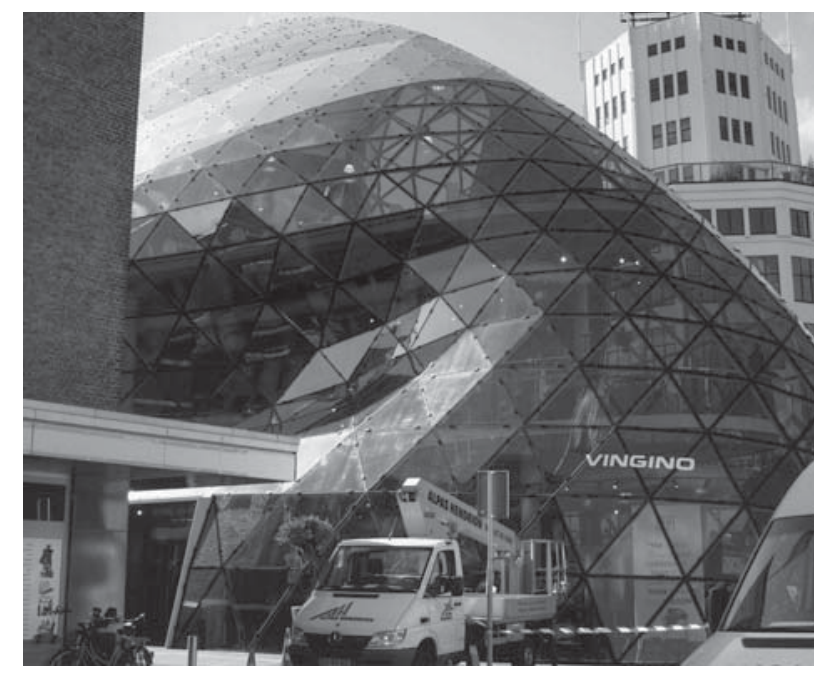

Fig 2. The blob in Eindhoven, The Netherlands (photo by T. Serafinavičius)

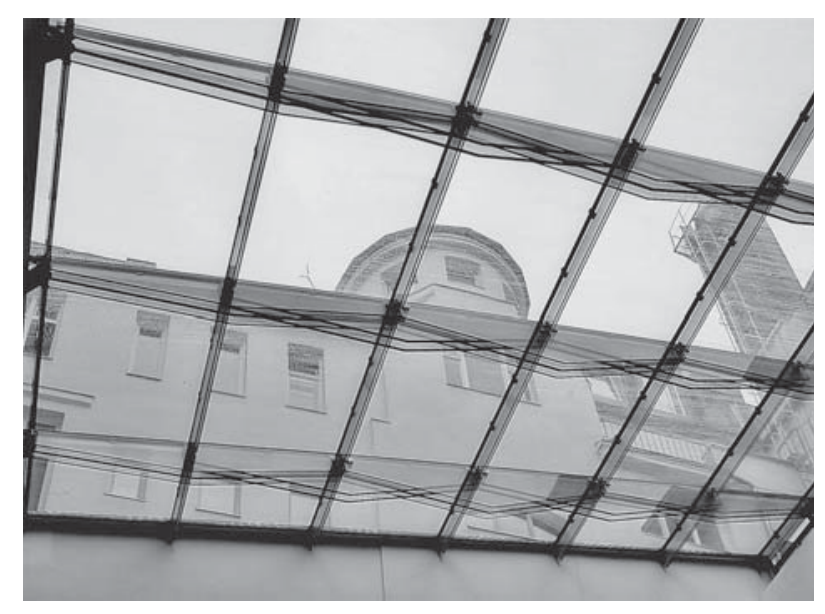

Fig. 3. Courtyard roof covering in Munich, Germany (photo by T. Serafinavičius)

\section{Structural Glass Beams (Table 1)}

Glass beams (Fig 4) are usually obtained gluing-up a few (4-6) glass sheets of 6-18 mm thickness. Due to their flat cross-section, glass beams have high slenderness for lateral torsion buckling. Collapse load is influenced not only by the imperfection of the glass beam but also by the stiffness of the sandwich represented by laminated safety glass. The sandwich consists of two materials - glass and PVB where glass is elastic material (E $\sim 70000 \mathrm{MPa})$ and PVB is viscous-elastic material with time and temperature dependent on behaviour.

Research on the reinforced glass beam focuses on the application of glass as structural building material and embodies the development of a novel safety concept for structural glass beams. This safety concept resembles reinforced concrete and is aimed at highly re- 
Table 1. A list of the overviewed structural glass beams

\begin{tabular}{|l|l|l|}
\hline Author, year & \multicolumn{1}{|c|}{ Title } & \multicolumn{1}{c|}{ Summary / Conclusions } \\
\hline Hof 2007 & $\begin{array}{l}\text { Investigations into } \\
\text { U-shaped glass } \\
\text { with a polyurethane } \\
\text { lacquer for splinter } \\
\text { shield }\end{array}$ & $\begin{array}{l}\text { Due to the novelty of using polyurethane coating for U-shaped glass profiles to assure the } \\
\text { remaining load bearing capacity, a large number of compatibility examinations with other } \\
\text { materials and elements were conducted. Special attention was paid to detecting discolor- } \\
\text { ations and loss of mechanical stability. An exceptional bearing of U-shape glass also de- } \\
\text { manded the examination of load bearing capacity under load. }\end{array}$ \\
\hline Veer 2007 & $\begin{array}{l}\text { Walking on air, } \\
\text { designing and } \\
\text { engineering a glass } \\
\text { bridge }\end{array}$ & $\begin{array}{l}\text { Using reinforced annealed float glass as the basic material, a design has been made so that } \\
\text { using only a single beam introduces high bending and torsion loads for which glass would } \\
\text { normally be considered unsuitable. Design calculations show that this type of structure is } \\
\text { possible. Using a novel approach to connecting the main and secondary beams was es- } \\
\text { sential. A new type of clamped on connection was developed and tested. This proves that a } \\
\text { frictional joint is possible in glass which allows for new and innovative designs. }\end{array}$ \\
\hline Louter 2007 & $\begin{array}{l}\text { Experimental } \\
\text { research on a 18 } \\
\text { m reinforced glass } \\
\text { beam model of a } \\
\text { scale 1:4, Part I }\end{array}$ & $\begin{array}{l}\text { 18 m structural glass beam is based on two concepts: 1) reinforced glass beams with stain- } \\
\text { less steel reinforcement; 2) adhesively bonded overlapping glass segments. The anchorage of } \\
\text { reinforcement at the ends of the beam provides extra redundancy in the system. Once full } \\
\text { detachment of reinforcement occurs due to progressive failure of the glass-reinforcement } \\
\text { bond at the post-initial failure stage, tensile forces can still be transferred (to the beam } \\
\text { heads) and the total beam collapse is prevented. }\end{array}$ \\
\hline
\end{tabular}

dundant structural glass beams by bonding a reinforcement section at the tensile edge of glass. The aim of the study is to experimentally, analytically and numerically validate and improve the concept and to formulate structural design guidelines for structural engineers to apply the concept in building practice (Louter 2007).

\section{Structural Glass Columns Plates for Floor, Roof, Facades and Railing Elements (Tables 2, 3)}

Glass plates (Fig. 5) are very widely used in such areas as elevation, guard rails, stairs or balcony flooring, roof construction. The use of laminated glass plates ensure security requirements in the event of collapse, the fragments of glass does not spread to the environment and does no harm for people.

Recently found investigations reveal differences in opinions and controversy about drill holes. Some authors argue that drilling holes is not the best method of fixing. Numerical simulations are carried out using finite element modelling programs, considering deflections of the whole frame and plate. The findings argue that the behaviour of glass design on the operation of side impact has not been fully explored and there is a need for additional researches.

Probabilistic methods for designing glass panels were developed in order to ensure safety requirements. The results obtained employing this program propose to apply the widest possible range of calculation methods at the same time estimating the reliability of the glass plate (application of theoretical load capacity calculations, 3D digital simulations by adopting software

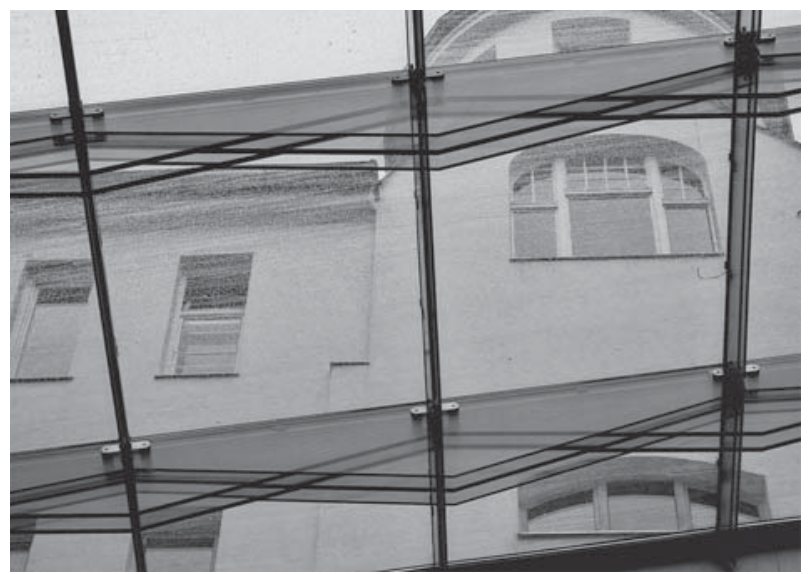

Fig. 4. Glass beams in roof construction, Munich (photo by T. Serafinavičius)

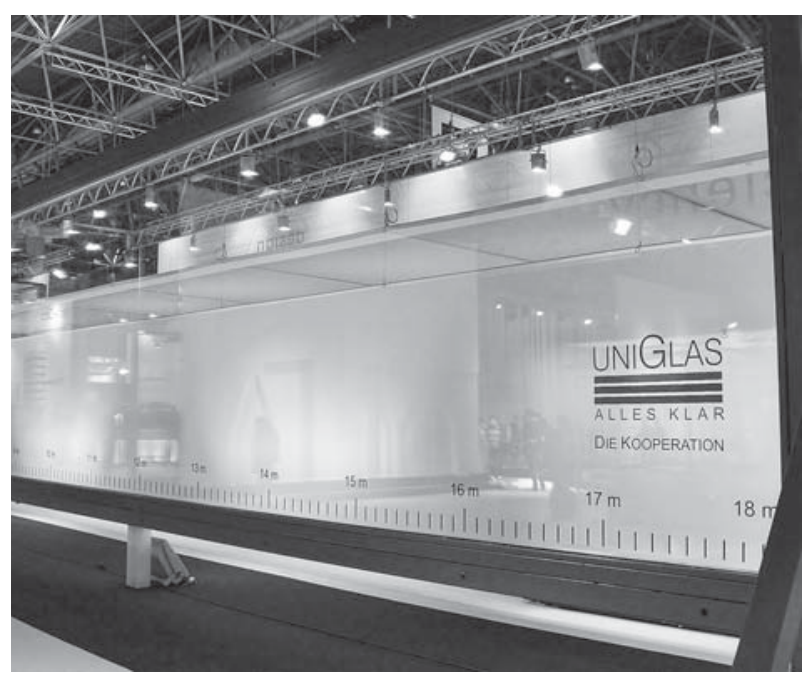

Fig. 5. $18 \mathrm{~m}$ length glass plate in Glastech-2010 (photo by T. Serafinavičius) 
Table 2. A list of the overviewed structural glass columns

\begin{tabular}{|l|l|l|}
\hline Author, Year & \multicolumn{1}{|c|}{ Title } & \multicolumn{1}{c|}{ Summary / Conclusions } \\
\hline Veer 1999 & $\begin{array}{l}\text { Developing a } \\
\text { transparent tubular } \\
\text { laminated column }\end{array}$ & $\begin{array}{l}\text { Transparent tubular laminated columns have strength and failure behaviour similar to } \\
\text { steel or aluminium columns. When fully developed, these columns can be used for load } \\
\text { bearing structures, combining the transparency of glass with the safety and strength } \\
\text { of steel. }\end{array}$ \\
\hline Luible & $\begin{array}{l}\text { Buckling design } \\
\text { of glass elements } \\
\text { under compression }\end{array}$ & $\begin{array}{l}\text { The column buckling strength of a compressed glass element depends mainly on the } \\
\text { initial deformation, glass thickness and the shear stiffness of the PVB foil interlayer. } \\
\text { The load carrying behaviour of laminated safety glass in compression depends strongly } \\
\text { on temperature and load duration due to shear connection with the viscous-elastic } \\
\text { PVB interlayer. Investigations showed that shear connection that can be simplified on } \\
\text { the safe side with an elastic approach might only be taken into account for short-term } \\
\text { loading like wind and impact. }\end{array}$ \\
\hline $\begin{array}{l}\text { Nieuwenhuijzen } \\
2005\end{array}$ & $\begin{array}{l}\text { The laminated } \\
\text { glass column }\end{array}$ & $\begin{array}{l}\text { The laminated glass column has safe failure behaviour in compression. The compres- } \\
\text { sion strength of the column depends on detailing the base and top of the column. The } \\
\text { actual compressive strength of the column cannot be determined due to the effect of } \\
\text { detailing on the base and top. }\end{array}$ \\
\hline $\begin{array}{l}\text { Blaauwendraad } \\
\text { 2008 }\end{array}$ & $\begin{array}{l}\text { Buckling laminated } \\
\text { glass columns. } \\
\text { Comparison and } \\
\text { replacement }\end{array}$ & $\begin{array}{l}\text { A new formula of buckling force does it in an elegant way and shows the dimensionless } \\
\text { parameter that controls the effectiveness of the foil between two glass layers. A unity } \\
\text { check of tensile stress can be done on the basis of a proper choice of initial deflection. }\end{array}$ \\
\hline
\end{tabular}

Table 3. A list of the overviewed structural glass plates

\begin{tabular}{|c|c|c|}
\hline Author, Year & Title & Summary / Conclusions \\
\hline Jacob 2007 & $\begin{array}{l}\text { Behaviour of } \\
\text { laterally loaded } \\
\text { glass panels with } \\
\text { an emphasis on } \\
\text { frame and panel } \\
\text { deflections }\end{array}$ & $\begin{array}{l}\text { Variability in the strength of glass has prevented significant breakage occurring on any } \\
\text { project when exposed to design wind pressure. Scratches in glass panels will result in } \\
\text { breakage. Breakage is generally not typical of high stress breakage but a single crack is } \\
\text { often attributed not to improper design but to other causes. This has generally provided } \\
\text { large stresses and deflections in the glass panel than actual. Real deflection in glass } \\
\text { panels is greatly influenced by the stiffness of the supporting frames. }\end{array}$ \\
\hline Huveners 2007 & $\begin{array}{l}\text { In-plane loaded } \\
\text { glass panel } \\
\text { (shear wall) }\end{array}$ & $\begin{array}{l}\text { No structural performance is ascribed to a glass facade to stabilize the building in the } \\
\text { present codes, but glass panes have compatibility to load in-plane. The idea of mobi- } \\
\text { lizing the in-plane stiffness of a plane is not new. Three systems with different joints } \\
\text { have been tested. The stress distribution and displacement of the system are analyzed. } \\
\text { The following conclusions can be drawn with regard to the safety and serviceability of } \\
\text { the facade. The next step is to determine the stress and deformation of the glass pane } \\
\text { calculating FEM. }\end{array}$ \\
\hline Lamela-Rey 2007 & $\begin{array}{l}\text { Probabilistic design } \\
\text { model for glazing } \\
\text { plates: a standard } \\
\text { proposal for } \\
\text { building }\end{array}$ & $\begin{array}{l}\text { This paper presents a proposal methodology to design monolithic and laminated glaz- } \\
\text { ing plates and consistently a design standard proposal for structural glass. The suggest- } \\
\text { ed design model is based on the non-linear plate theory and the elastic and visco-elastic } \\
\text { material behaviour of element constituents, glass and PVB, together with criteria for } \\
\text { fracture mechanics and probabilistic considerations in contrast to conventional deter- } \\
\text { ministic design models based on material admissible stress. Moreover, some of them } \\
\text { are not based on clearly specified probabilistic models and do not take into account the } \\
\text { non-linear theory of glass plates. }\end{array}$ \\
\hline Englhardt 2007 & $\begin{array}{l}\text { Hybrid structural } \\
\text { elements- an } \\
\text { innovative high } \\
\text { filigree glass-steel- } \\
\text { system. }\end{array}$ & $\begin{array}{l}\text { As represented in this paper, glass plate structures have a high potential as a load bear- } \\
\text { ing structural member in architectural design. With the use of glass panes as surface } \\
\text { structures, the activation of high load-bearing potential for in-plane load transfer is } \\
\text { possible. The simple and uniform structure of design and construction leads to complex } \\
\text { and less cost intensive production. The use of these systems raises the degree of trans- } \\
\text { parency for building envelopes and break new grounds in high filigree architectural } \\
\text { design. The presented glass-steel-girder should be the first step to such new applications } \\
\text { of glass in architecture and structural engineering. }\end{array}$ \\
\hline Teixidor 2010 & $\begin{array}{l}\text { Glass-honeycomb } \\
\text { composite panels }\end{array}$ & $\begin{array}{l}\text { The bending stiffness of insulating glass units can be significantly improved by includ- } \\
\text { ing an aluminium honeycomb core continuously bonded to both glass panes. This ar- } \\
\text { rangement also offers a number of additional advantages, ranging from improved post- } \\
\text { breakage behaviour to a particular translucent look. } \\
\text { This paper has shown how glass-honeycomb composite panels are able to meet the } \\
\text { structural and privacy requirements of many facade, floor and roof applications and to } \\
\text { provide unique visual appearance to the cladding of buildings. }\end{array}$ \\
\hline
\end{tabular}


the finite element method, tests on natural structures using the actual size or scale). It is possible to exercise more detailed exploration adjusting the values of safety factors.

The findings lead to further research in order to discover the ways to achieve minimum stresses on the main plate. There are full filled experiments with hybrid design (glass and steel) which opens the way to develop a hybrid of glass and steel trusses.

\section{Steel and Glass Fixing, Adhesive Connections (Table 4)}

One of the most sensitive places of glass structures are the areas of installing connections (Fig. 6). Fixing glass members in supporting parts usually has several types.

(Siebert 2007), (Bernard 2008) showed that connections having drilled holes and steel rivets can withstand the force of up to $143 \mathrm{kN}$. It is possible to use special glue for joints (Weller et al. 2008). The main problem of the tempered glass joint is residual stresses arising after the complex thermal process and the general behaviour of the node assessing unilateral friction and its losses between glass and metal connector (Dong To et al. 2007). Test results on different methods fastening glass plate elements to the building bracings (Mocibob et al. 2007) show that better stability is achieved using steel bolts of larger diameter, although it does not depend on fastening conditions.

The strength of adhesive bonds is generally assumed to be highly dependent on the quality of workmanship. This fact makes controlling bodies hesitant to allow adhesive bonding connections in structural glass engineering. However, little is known quantitatively about the sensitivity of adhesive bond strength to substandard workmanship. Therefore, the influence of building-site related contaminations of the bond strength of three different two-component epoxies was experimentally investigated. Importantly, not all adhesives were affected much by contaminations. With the particle based contaminations, the grain size (in relation to adhesive layer thickness) seems to be the major variable. Cement, plaster and small grain sand had a comparable influence on adhesive strength. Large grain sand deviated and generally had much more influence. This study underlines the relevance of sensitivity to application quality as an adhesive property to investigate and adjust adhesive selection. The general wariness of execution errors at least with regards to contaminations appears not to be completely justified. The appli- cation of robust adhesives (insensitive to in application errors) could overcome many of the current hesitations, although the proper execution of adhesive bonds should obviously always be aimed at (Bos et al. 2010).

During a research project, the Institute of Building Construction has already examined the performance of light and UV curing acrylates in glass construction in which different adhesives have been tested (Fig. 7).

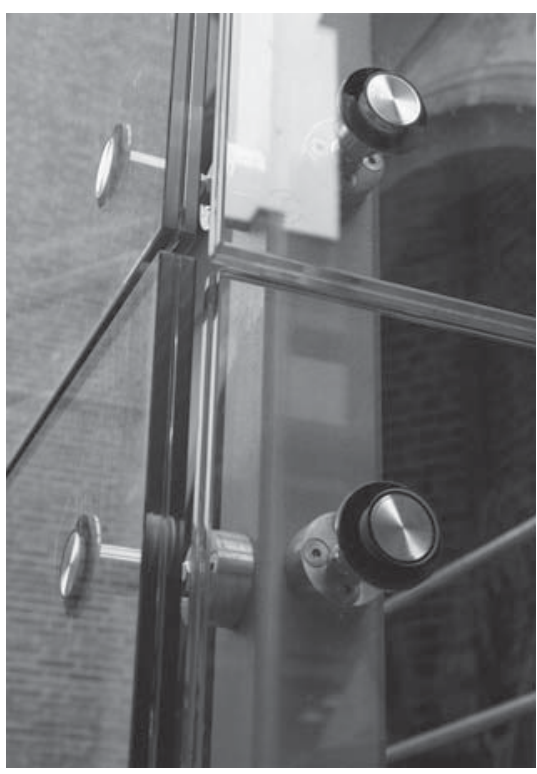

Fig. 6. Point-fix connection to tempered and laminated structural glass (photo by T. Serafinavičius)

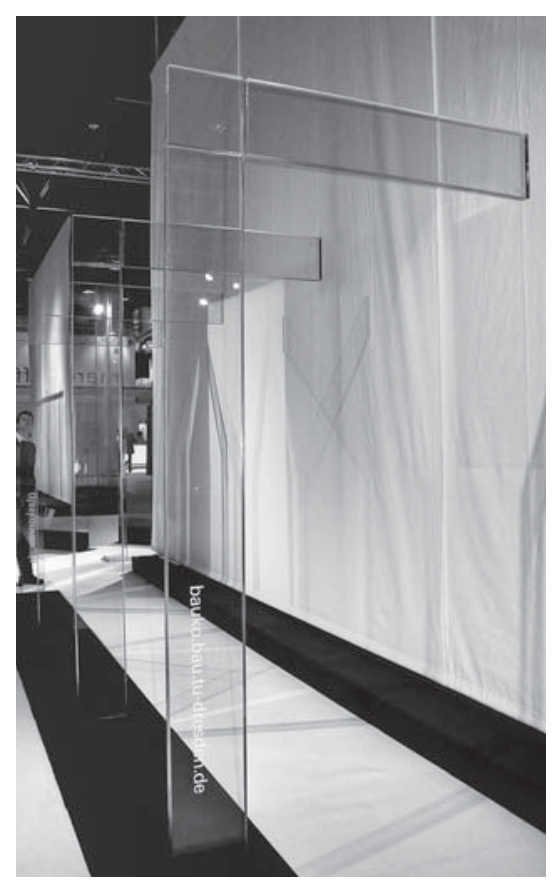

Fig. 7. Laminated structural glass column and beam with adhesive connection in Glastech-2010 (photo by T. Serafinavičius) 
Table 4. A list of the overviewed structural glass connections

\begin{tabular}{|c|c|c|}
\hline Author, Year & Title & Summary / Conclusions \\
\hline $\begin{array}{l}\text { Quy-Dong To } \\
2007\end{array}$ & $\begin{array}{l}\text { A coupled numerical } \\
\text { and experimental } \\
\text { approach for failure } \\
\text { analysis of tempered } \\
\text { glass stiffeners with } \\
\text { pin joints. }\end{array}$ & $\begin{array}{l}\text { This paper systematically studies the failure process of tempered glass structures with } \\
\text { pin-loaded joints applying a coupled experimental-numerical method. First, the tem- } \\
\text { pering process is simulated numerically and validated by photo-elasticity measures. } \\
\text { As a result, residual stress as well as the field of tensile strength can be precisely de- } \\
\text { termined. Second, the mechanical characteristics of the resin used in the joint are } \\
\text { experimentally identified and a damage model is proposed for it. Third, a numerical } \\
\text { procedure is elaborated to analyze the mechanical behaviour of tempered glass struc- } \\
\text { tures with pin-loaded joints up to failure. The obtained experimental and numerical } \\
\text { results of this structure are compared. }\end{array}$ \\
\hline Bernard 2008 & $\begin{array}{l}\text { Optimization of bolted } \\
\text { connections in load } \\
\text { bearing glass elements. }\end{array}$ & $\begin{array}{l}\text { This study deals with the context of structural glass and the accent is related to struc- } \\
\text { tural connections between glass panes. This study has shown that the holes of type } \\
\text { b2 (large diameter and large chamfer, with a cylindrical part equal to } 1 / 6 \text { of plate } \\
\text { thickness) present the best geometry among the whole studied ones. Indeed, thermal } \\
\text { tempering reinforcement is the most effective and this kind of the hole is the most } \\
\text { resistant to the in-plane loading of the metallic connector. Finally, this study provides } \\
\text { other results such as the influence of the initial prestressing of the connector on glass } \\
\text { and the crack healing effect of thermal tempering. }\end{array}$ \\
\hline Macibob 2007 & $\begin{array}{l}\text { Glass panel under } \\
\text { in-plane shear } \\
\text { loading: experimental } \\
\text { investigation into } \\
\text { structural glass panel } \\
\text { point support. }\end{array}$ & $\begin{array}{l}\text { When using glazing as a stabilizing element in buildings, the load should be ade- } \\
\text { quately introduced in the glass panel providing sufficient shear load-carrying capac- } \\
\text { ity. Glass specimens were tested under axially and eccentrically applied load with } \\
\text { rigid and pinned point supports under compression and tension. The rigidity of the } \\
\text { system depends on bolt diameters rather than on support conditions. The eccentric } \\
\text { rigid system demonstrates additional safety due to residual resistance. A weak bolt in } \\
\text { the eccentric test gives system ductility. The use of the injected mortar was found to } \\
\text { be an adequate solution to uniform load introduction in the laminated glass as well } \\
\text { as to load transferring from bolts to glass. }\end{array}$ \\
\hline Siebert 2007 & $\begin{array}{l}\text { Safety aspects of } \\
\text { point-fixed glass } \\
\text { constructions. }\end{array}$ & $\begin{array}{l}\text { The major subject is point-bearings of glass elements: problems of modelling and cal- } \\
\text { culation to get satisfying, close-to-reality results and further special detail problems } \\
\text { are to be recognized and solved. It is important that glass has no "intelligent behav- } \\
\text { iour of material" like the yielding of steel in case of high punctual stress. Important } \\
\text { points are the residual resistance of glass and behaviour after break. }\end{array}$ \\
\hline
\end{tabular}

A special focus was given on the static and dynamic stress of lamination, the strengths of different adhesive samples and ageing resistance to the joints. These adhesives are analysed both generally as bulk material and in applications as a joint between glass and metal. The use of dumb-bell specimens is recommended to analyze material behaviour under a variety of influential factors such as temperature and testing speed. A matter of a particular interest was testing in situ specimens. To determine the material properties of bonded joints, different specimens with varying geometries can be used. In case of glass construction configurations, the butt-bonded hollow cylinder is particular suitable. Construction had to be modified for joints connecting glass components. Constructions having punctually bonded joints are tested to demonstrate the potential use of acrylic joints in glass treatments. Some components are exposed to natural weathering in order to examine the effects of ageing on the adhesive (Vogt et al. 2010).
To bond glass and metal, ultrasonication is common practice in electronic industry for connecting glass-ceramic carrier materials and conductors. In solar industry, contact areas are placed onto PV glass panels and UltraSonic glass-to-metal Bond (USB) seals vacuum tubes similar to light bulb industry. Using an ultrasonic "sonotrode" punch, glass and metal will merge as if welded together (Friedl et al. 2010).

\section{Calculation, Standards / Codes and Measurements}

While designing glass structures, difficulties concerning their design standards arise. As this is a relatively new field, it is currently governed by only a few standards: DIN 18008 in Germany, Austrian OORM 3716, Canadian CAN-CGSB-12.20-M89, the United States code ASTM-E1300-97, Australian- AS 1288-94, United Kingdom- BS 6262 and the European projects of prEN 13474-1, prEN 13474-2, prEN 13474-3 (Siebert 2007; Beer 2005; Calderon 2007). However, these codes include only a small field of glass adaptation in 
design and construction. The existing codes include the basic rules and concepts, perimeter glazing and fixation by the spot, additional requirements for handrails and flooring and special structures.

Standard DIN 18008 provides rules for design and construction as well as specifications for required experimental verifications. The load-bearing capacity, positional permanence and usability of the glazed structures under planned action are dealt with. The standard was designed so that additional standard parts can be added. DIN 18008 standard series, "Glass in Building - Design and Construction Rules" is intended to consist of the following parts: Part 1: Terms and general bases; Part 2: Linearly supported glazings; Part 3: Point fixed glazings (in preparation); Part 4: Additional requirements for fall-secured glazings (in preparation); Part 5: Additional requirements for walk able glazings (in preparation); Part 6: Additional requirements for glazings accessible for cleaning and maintenance measures (in preparation); Part 7: Special structures (in preparation).

In Germany, technical rules for glass construction are available and include technical rules for glazing acting as anti-drop device / railing (TRAV), technical rules for linear supported glazing (TRLV) and technical rules for point supported glazing (TRPV).

An ordinary design of glass structures is carried out by modelling static loads until convergence on the allowable stresses. All structures of the building are modelled as an assembly with applying 3D finite element programs as well as individual elements or complicated connections. Temperature changes are also evaluated in calculations. The majority of authors in their publications mention that the application of hybrid structural glass and steel structures / connections based only on calculations is not entirely reliable and additional tests must be carried out (Beer 2005).

There are also new measuring devices for measuring stress in glass (Fig. 8). Ilis StrainMatic is the automatic and objective measurement of stress in glass, plastics and other translucent materials. Also, the measuring machine includes software (Fig. 9) that allows immediately record and analyze the stress value in glass specimen (Ilis.de).

The increasing popularity of public buildings from glass and their effects on the environment and human security made a concern in Russia. In 2007, the Russian Parliament (Duma) considered a technical description of rules for the safety of glass and its

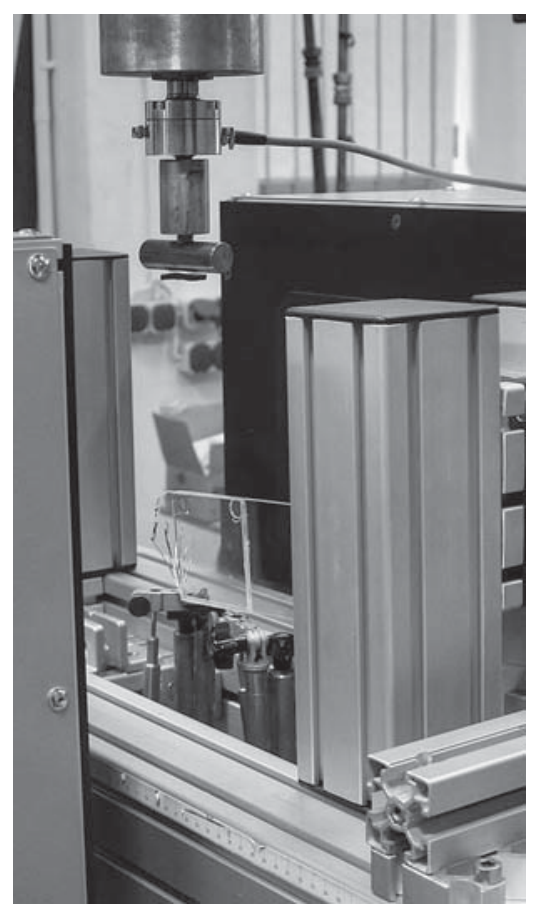

Fig. 8. Glass specimen in StrainMatic measuring machine (photo by T. Serafinavičius)

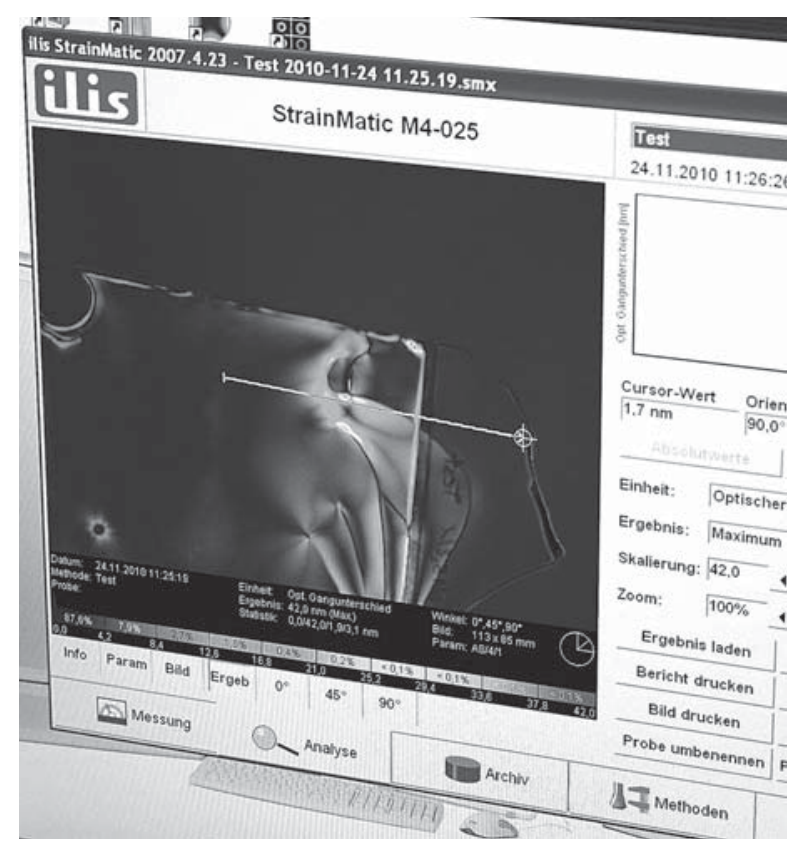

Fig. 9. Stress image in glass on StrainMatic Software (photo by T. Serafinavičius)

products used in buildings and construction. The main purpose of this document is to establish such regulations and conditions that should reduce the risks of life and health, create certification procedures for designers of glass buildings and structures and develop the use of modern glass and its products in structures (Chesnokov et al. 2007). 
At present, and there are no normative documents regulating flat glass calculation methods for elasticplastic materials in Russia. For calculating flat glass strength used in glass translucent structures, a testing centre of Samara State University of Architecture and Civil Engineering made experimental and theoretical research on flat glass samples at lateral bending applying uniformly distributed load. The researchers showed that the existing theories of plates based on applying elastic-plastic materials and the ratio of a short side of a glass sheet to its thickness ( $b$ / h) of less than 100 could not be used for calculating flat glass strength (Zubkov et al. 2010).

Japanese scientists published the first normative documents in 1971 (Kikuta et al. 2001). They are constantly improving, thus assessing changes in glass production technology, a greater thickness of glass and more accurate wind loads by using corrections to safety factors.

China is taking the first steps of standardization in glass construction (Xinyong et al. 2007). However, there are not so many English papers on glass investigations in China or India because of the language barrier. This situation is also typical of all European scientists as some have problems with the Russian language.

The majority of glass structural design standards were questioned because of the simplicity of calculation and were based on determining crude strength - force acting on the cross-sectional area or on the contrary very complicated calculation methods based on complex empirical expressions that can lead to serious mistakes or inaccuracies in calculated results. Therefore, designers dealing with structural glass buildings generally have to carry out design calculations parallel with performing natural testing in laboratories which cannot provide real construction site conditions, and thus builders could make inaccuracies and errors (Beer 2005).

\section{Conclusions and Summary}

From the performed review of the study on structural glass and its structures, the following conclusions are presented:

- The design of glass bearing structures is still a big challenge for engineers.

- The majority of authors argue about using glass structures practically, but not clearly disclose the reasons.
- One of difficulties in the construction of glass structures is the installation of connections.

- No scientific articles related to investigation or tests on structural glass and design codes in Lithuania have been found.

- The major part of authors mention that calculating hybrid structural glass and steel structures / connections is not entirely reliable, and therefore parallel tests must be carried out.

- Higher content of articles on the exploration of plates under natural experiments and numerical experimentation using the finite element method were observed.

- It was established that less studies on fatigue were exercised.

- The major part of tests is carried out using individual and separate elements. Only a few articles describing all construction work and monitoring the behaviour of structural glass were examined.

Structural glass is not a fully studied subject. A limited amount of testing results does not warrant for believing in the behaviour of glass structures. Further research on the assembly methods of glass elements, frictional joints, developed elements of shape I or square / rectangular shapes of glass elements, adhesive connections and the fatigue of glass elements or the whole structure could be carried out.

The undertaken review suggests more testing and research in the field of world structural glass. Thus, this review is a very temporary thing and requires keeping a consistent interest and additional knowledge.

\section{Discussion}

Glass offers a wide variety of possible applications for realizing even the most ambitious designs in architecture. Within the period of the past two decades, it has experienced an unparalleled burst of innovations. For planners and engineers, this means working constantly employing this high-performance material.

Glass is relatively cheap material, but the cost of glass building increases the total price, which means that profits are obtained from the existing stereotype, but at the price of material.

In particular, the greatest cities worldwide face the problem of cleaning buildings. This problem is very closely related to glass structure and social matters, because a lot of people die every year when cleaning buildings. 
With regard to the structure or the building life cycle, the recycling aspect should be paid more attention. Glass structure could possibly be more environmentally friendly and responsible.

Some further research should aim at the influence of contaminations and ageing on the durability of structural adhesive bonds.

Although glass structures have been studied for 30 years in Europe, however, so far, no consensus about the aspects and rules of design has been reached. Glass Euro code is moving a very slowly way. Structural glass in the construction education pack is improperly developed for bringing information for students at universities.

\section{References}

Beer, B. 2005. Structural Glass Engineering- a Review of Project Specific Testing, in The Leading International Architectual and Automotive Glass Conference "Glass Processing Days", Tampere, Finland, June 17-20, 2005. Tampere, 2005.

Bennison, J. S.; Smith, C. A.; Duser, A. V.; Jagota, A. 2001. Strength of Laminated Safety Glass, in The $7^{\text {th }}$ International Conference on Architectural and Automotive Glass "Glass Processing Days 2001”, Tampere, Finland, June 18-21, 2001. Tampere, 368-371.

Bernard, F. 2008. Optimization of Bolted Connections in Loadbearing Glass Elements, in Challenging Glass, Conference on Architectural and Structural Applications of Glass: selected papers. Ed. by Bos, Louter, Veer. May 2008, Delft, Netherlands. TUDelft, 660.

Blaauwendraad, J. 2008. Buckling of Laminated Glass Columns. Comparison and Replacement, in Challenging Glass, Conference on Architectural and Structural Applications of Glass: Selected papers. Ed. by Bos, Louter, Veer. May 2008, Delft, Netherlands. TUDelft, 660.

Bos, F.; Veer, F.; Romein, T.; Nijsse, R. 2005. The Evaluation of the All Transparent Pavilion Project, in The Leading International Architectual and Automotive Glass Conference "Glass Processing Days", Tampere, Finland, June 17-20, 2005. Tampere, 710.

Bos, F.; Hulle, A.V.; Six, B.; Belis, J. 2010. Influence of buildingsite contaminations on adhesive bond strength, in Engineered Transparency. International Conference at Glasstec, Dusseldorf, Germany 29-30 September 2010, 189-197.

Boxheimer, K. 2007. Cyclic fatique of glass panels, in The Leading Conference on Architectural and Automotive Glass "Glass Performance days 2007", Tampere, Finland, June 1518, 2007. Tampere, 452-454.

Detail.de Portal for Architecture [online]. 2004. Courtyard Roof Covering in Munich. Available on the Internet: <gopher:// www.detail.de/rw_5_Archive_En_HoleArtikel_5416_ Artikel.htm.>.

DIN 18008-1 Glas im Bauwesen - Bemessungs- und Konstruktionsregeln Teil 1: Begriffe und allgemeine Grundlagen [Glass in Building - Design and construction rules - Part
1: Terms and general bases]. DIN Deutsches Institut für Normung. Berlin, 2010, 14.

DIN 18008-2 Glas im Bauwesen - Bemessungs- und Konstruktionsregeln Teil 2: Linienförmig gelagerte Verglasungen [Glass in Building - Design and construction rules - Part 2: Linearly supported glazings]. DIN Deutsches Institut für Normung. Berlin, 2011, 13.

Emelianova, O. A.; Chesnokov, A. G. 2007. Project of Russian law: technical order "About safety of glass and its products used in buildings and constructions", in The Leading Conference on Architectural and Automotive Glass "Glass Performance days 2007”, Tampere, Finland, June 15-18, 2007. Tampere, 455-457.

Englhardt, O.; Bergmeister, K. 2007. Hybrid structural elements an innovative high filigree glass-steel-system, in The Leading Conference on Architectural and Automotive Glass "Glass Performance days 2007", Tampere, Finland, June 15-18, 2007. Tampere, 134-137.

Friedl, W. 2010. USB: UltraSonic glass-to-metal Bond- a new technique dovetails flat glass and metal, in Engineered Transparency. International Conference at glasstec, Dusseldorf, Germany 29-30 September 2010, 207-211.

Hof, P. 2007. Investigations on U-shaped glass with a polyurethane lacquer for splinter shield, in The Leading Conference on Architectural and Automotive Glass "Glass Performance days 2007”, Tampere, Finland, June 15-18, 2007. Tampere,. 314-316.

Huveners, E. M. P; Herwijnen, F.; Soetens, F.; Hofmeyer, H. 2007. In-plane loaded glass pane (shear wall), in The Leading Conference on Architectural and Automotive Glass "Glass Performance days 2007", Tampere, Finland, June 15-18, 2007. Tampere, 362-365.

Ilis.de Ilis gmbh web page [online]. 2011. Available on the Internet: <http://www.ilis.de/en/products.html>.

Jacob, L.; D’Cruz, J. 2007. Behaviour of laterally loaded glass panels with an emphasis on frame and panel deflections, in The Leading Conference on Architectural and Automotive Glass "Glass Performance days 2007", Tampere, Finland, June 15-18, 2007. Tampere, 419-421.

Kikuta, M.; Murakami, T.; Aratani, S. 2001. Conception of A New Notification of Building Glass Design in Japan, in The Leading Conference on Architectural and Automotive Glass "Glass Processing Days 2001", Tampere, Finland, June 18-21, 2001. Tampere, 688-691.

Lamela-Rey, M. J.; Fernandez-Canteli, A.; Garcia-Prieto, M. A., Castillo-Ron, E. 2007. Probabilistic design model for glazing plates: a standard proposal for building, in The Leading Conference on Architectural and Automotive Glass "Glass Performance days 2007”, Tampere, Finland, June 15-18, 2007. Tampere, 581-583.

Louter, C.; Veer, F. 2007. Experimental research on scale 1:4 models of an $18 \mathrm{~m}$ reinforced glass beam, part I, in The Leading Conference on Architectural and Automotive Glass "Glass Performance days 2007”, Tampere, Finland, June 15-18, 2007. Tampere, 87-92.

Luible, A.; Crisinel, M. 2005. Buckling of glass elements under compression. Using the World-Wide Web to Deliver Complex Electronic Documents: [online], [cited December 12, 2009]. Available on the Internet: <www.glassfiles.com>. 
Mocibob, D.; Crisinel, M. 2007. Glass panel under in-plane shear loading: Experimental investigation on structural glass panel point support, in The Leading Conference on Architectural and Automotive Glass "Glass Performance days 2007", Tampere, Finland, June 15-18, 2007. Tampere, 380-383.

Nieuwenhuijzen, E. J.; Bos, F. P.; Veer, F. A. 2005. The Laminated Glass Column. The Leading International Architectual and Automotive Glass Conference "Glass Processing Days", Tampere, Finland, June 17-20, 2005. Tampere, 710.

O'Callaghan, J; Coult, G. 2007. An all glass cube in New York City, in The Leading Conference on Architectural and Automotive Glass "Glass Performance days 2007", Tampere, Finland, June 15-18, 2007. Tampere, 98-101.

prEN 13474-1 Glass in buildings- Design of glass panes- Part 1: General basis of design. European committee for standardization. Brussels, 1999, 28.

prEN 13474-1 Glass in buildings- Design of glass panes- Part 2: Design for uniformly distributed loads. European committee for standardization. Brussels, 2000, 54.

prEN 13474-1 Glass in buildings- Determination of the strength of glass panes- Part 3: General method of calculation and determination of strength of glass by testing. European committee for standardization. Brussels, 2007, 32.

Quy-Dong, T.; Qi-Chang, H.; Cossavella, M.; Morcant, K.; Panait. A.; Yvonnet, J. 2007. A coupled numerical and experimental approach for failure analysis of tempered glass stiffeners with pin joints, in The Leading Conference on Architectural and Automotive Glass "Glass Performance days 2007”, Tampere, Finland, June 15-18, 2007. Tampere, 437-441.

Siebert, B. 2007. Safety aspects of point-fixed glass constructions, in The Leading Conference on Architectural and Automotive Glass "Glass Performance days 2007", Tampere, Finland, June 15-18, 2007. Tampere, 432-436.

Siebert, G. 2007. New German DIN standard DIN 18008 for design of glass elements, in The Leading Conference on Architectural and Automotive Glass "Glass Performance days 2007", Tampere, Finland, June 15-18, 2007. Tampere, $460-462$.

Siebert, G. 2007. Design of glass structures based on fracture mechanics and its integration in national and European design codes, in The Leading Conference on Architectural and Automotive Glass "Glass Performance days 2007", Tampere, Finland, June 15-18, 2007. Tampere, 591-593.
Teixidor, C. 2010. Glass-honeycomb composite panels, in Engineered Transparency. International Conference at glasstec, Dusseldorf, Germany 29-30 September 2010, 423-430.

TRAV Technische Regeln für die Verwendung von absturzsichernden Verglasungen [Technical Rules for glazing acting as antidrop device / railing]. 2003. Mittlg. DIBt, Berlin, 17.

TRLV Technische Regeln für die Verwendung von linienförmig gelagerten Verglasungen [Technical Rules for linear supported glazing]. Mittlg. DIBt, Berlin, 2006, 9.

TRPV Technische Regeln für die Bemessung und die Ausführung punktförmig gelagerter Verglasungen [Technical Rules for point supported glazing]. Mittlg. DIBt, Berlin, 2006, 5.

Vogt, I.; Weller, B.; Zastrau, B. 2010. Transparent and strong bonded joints with acrylates, in Engineered Transparency. International Conference at glasstec, Dusseldorf, Germany 29-30 September 2010, 199-206.

Veer, F. A.; Bosma, M.; van Swieten, P. M. J.; Louter, P. C.; Romein, T. 2007. Walking on air, designing and engineering a glass bridge, in The Leading Conference on Architectural and Automotive Glass "Glass Performance days 2007", Tampere, Finland, June 15-18, 2007. Tampere, 244-246.

Veer, F. A.; Louter, P. C.; Bos, F. P.; Romein, T.; van Ginkel, H.; Riemslag, A. C. 2008. The strength of architectural glass, in Challenging Glass, Conference on Architectural and Structural Applications of Glass: Selected papers. Ed. by Bos, Louter, Veer. May 2008, Delft, Netherlands. TUDelft, 660.

Veer, F. A.; Pastunink, J. R. 1999. Developing a Transparent Tubular Laminated Column, in International Conference on Architectural and Automotive Glass "Glass Processing Days 1999", Tampere, Finland, June 13-16, 1999. Tampere, 277-280.

Wellershoff, F.; Sedlacek, G. 2003. Glass Pavilion Rheinbach - Stability of Glass Columns, in The Leading International Glass Conference "Glass Processing Days 2003", Tampere, Finland, June 15-18, 2003. Tampere, 316-318.

Weller, B.; Vogt, I. 2008. Calculating Bonded Joints with Acrylates, in Challenging Glass, Conference on Architectural and Structural Applications of Glass: Selected papers. Ed. by Bos, Louter, Veer. May 2008, Delft, Netherlands. TUDelft, 660.

Zubkov, V.; Kondratyeva, N. 2010. Flat glass strength in facade systems coverings and floorings of buildings and structures, in Engineered Transparency. International Conference at glasstec, Dusseldorf, Germany 29-30 September 2010, 63-70. 


\section{STATYBINIO STIKLO IŠŠŪKIAI: APŽVALGA}

\section{T. Serafinavičius, A. A. Kvedaras}

Santrauka. Straipsnyje pateikiama statybinio stiklo tyrimų literatūros apžvalga ir sisteminga mokslinių straipsnių schema, taikant bandymų metodus ir teorinị vertinimą. Europos valstybių mokslininkai jau prieš 30 metų ị stiklą pažvelgė naujai, išryškindami stiklo įvairiapusiškumą ir naudojimą realizuojant architektūrinius ir konstrukcinius sprendimus - stiklas vertinamas kaip apkrovas perimanti laikančioji konstrukcija. Šiuo metu pasaulyje ir Lietuvoje jaučiamas pagyvejimas, sujudimas, susidomejjimas naujuoju stiklo ir šviesos antplūdžiu. Skaidrumas, geros mechaninès charakteristikos (gniuždomasis stipris), maža gamybos savikaina ir plačios perdirbimo galimybės (aplinkosauga) - visos šios savybės lẻmė dabartinị stiklo populiarumą. Viena svarbesnių stiklo savybių, suteikiančių šiai medžiagai paslaptingumo, yra stiklo pralaidumas šviesai. Straipsnyje atskleidžiamos mažiau ištirtos statybinio stiklo naudojimo sritys. Pagrindiniai svarbiausių tolesnių tyrimų krypčių tikslai ir uždaviniai suformuluoti remiantis šia apžvalga.

Reikšminiai žodžiai: statybinis stiklas, laminuotas stiklas, grūdintasis stiklas, elgsena, struktūriniai elementai, sistemine schema.

Tomas SERAFINAVIČIUS. PhD student at the Department of Steel and Timber Structures, Vilnius Gediminas Technical University (VGTU), Lithuania. Tomas Serafinavičius, born 1984, received his BA degree in civil engineering from Vilnius Gediminas Technical University in 2007 and MA degree in civil engineering - from Kaunas University of Technology in 2009. He is member of IABSE. Research interests: Behaviour of the Structural Glass, Calculation methods and codes of glass.

Audronis Kazimieras KVEDARAS. Prof. Dr. Habil. at the Department of Steel and Timber Structures and the Director of the Innovatory Scientific Institute of Special Structures "Kompozitas" of Vilnius Gediminas Technical University (VGTU), Lithuania. Audronis Kazimieras Kvedaras, born 1937, received his degree in civil engineering from Kaunas Polytechnic Institute in 1960. Candidate of Technical Sciences (PhD) at Kaunas Polytechnic Institute, 1968 (Nostrificated as Doctor of Sciences, 1993). Dr. Habil. at Vilnius Gediminas Technical University, 2000. A member of IABSE and ASCCS, an expert invited to work for NATO $(1996,2000)$. Fields of research: steel, composite steel-concrete and timber-concrete structures, structures from structural glass. 